\title{
Organotin(IV) derivatives with 5,7-disubstituted-1,2,4-triazolo [1,5-a]pyrimidine and their cytotoxic activities: The importance of being conformers
}

\author{
Maria Assunta Girasolo ${ }^{\mathrm{a}, *}$, Alessandro Attanzio $^{\mathrm{a}}$, Piera Sabatino ${ }^{\mathrm{b}}$, Luisa Tesoriere ${ }^{\mathrm{a}}$, Simona Rubino ${ }^{\mathrm{a}}$, \\ Giancarlo Stocco ${ }^{\text {a }}$ \\ ${ }^{a}$ Dipartimento STEBICEF, Parco d'Orleans II, Viale delle Scienze - Ed. 16, 90128 Palermo, Italy \\ ${ }^{\mathrm{b}}$ Dipartimento di Chimica G. Ciamician, Università di Bologna, via F. Selmi 2, 40126 Bologna, Italy
}

\section{A R T I C L E I N F O}

\section{Article history:}

Received 24 April 2014

Received in revised form 9 July 2014

Accepted 10 July 2014

Available online 18 July 2014

\section{Keywords:}

Triazolopyrimidine

Organotin(IV)

Apoptosis

In vitro anticancer activity

Crystal structure

\begin{abstract}
A B S T R A C T
The organotin(IV) compounds $\mathrm{Me}_{2} \mathrm{SnCl}_{2}(\mathrm{dbtp})(\mathbf{1}), \mathrm{Me}_{2} \mathrm{SnCl}_{2}$ (dbtp $)_{2}(\mathbf{2}), \mathrm{Et}_{2} \mathrm{SnCl}_{2}(\mathrm{dbtp})(\mathbf{3}), \mathrm{Et}_{2} \mathrm{SnCl}_{2}(\mathrm{dbtp})_{2}$ (4), $\mathrm{Et}_{2} \mathrm{SnCl}_{2}$ (dptp) (5), ${ }^{n} \mathrm{Bu}_{2} \mathrm{SnCl}_{2}(\mathrm{dbtp})_{2}$ (6), ${ }^{n} \mathrm{Bu}_{2} \mathrm{SnCl}_{2}$ (dptp) (7), $\mathrm{Ph}_{2} \mathrm{SnCl}_{2}$ (dbtp) (8), $\mathrm{Ph}_{2} \mathrm{SnCl}_{2}(\mathrm{EtOH})_{2}$ $(\operatorname{dptp})_{2}(\mathbf{9})$, where dbtp = 5,7-di-tert-butyl-1,2,4-triazolo[1,5-a]pyrimidine and $\mathbf{d p t p}=5,7$-diphenyl1,2,4-triazolo [1,5-a]pyrimidine, have been tested by MTT for their cytotoxic activity on three tumor cell lines, HepG2 (human hepatocellular carcinoma), HeLa (human cervix adenocarcinoma) and MCF-7 (human breast cancer). Except for $\mathbf{1}$ and 2, which were ineffective, all compounds significantly showed a dosedependent anti-proliferative effect against the three cell lines. By calculated $\mathrm{IC}_{50}$ values, the cytotoxicity of the complexes followed the order ${ }^{n} \mathrm{Bu}>\mathrm{Ph}>\mathrm{Et}>\mathrm{Me}$ for all the selected tumor cells. The cell death of HepG2, induced by organotin(IV) compounds 6-9, was considered to be apoptotic by measuring the exposure of phosphatidylserine to the outer membrane and observing the typical apoptotic morphological change by acridine orange/ethidium bromide staining. Flow cytometric analysis of propidium iodidestained cells also demonstrated that organotin(IV) complexes caused apoptosis of HepG2 cells through cell arrest at G0-G1 phase. The crystal structure of 7, investigated by X-ray diffraction study, exhibited a distorted trigonal bipyramidal geometry with $\mathrm{N}, \mathrm{Cl}$ as axial atoms and $\mathrm{Cl}$ and butyl groups in the equatorial plane. The triazolopyrimidine unit coordinates to the $\mathrm{Sn}$ atom through $\mathrm{N}(3)$ in a monodentate mode. Two conformational isomers (molecule $\mathbf{A}$ and $\mathbf{B}$ in the crystallographic independent unit) are co-crystallized in the solid state, a phenomenon that has been observed only occasionally. Conformational mobility of the cytotoxic complex $\mathbf{7}$ can sum up to the ligands ability to form H-bonds and $\pi \cdots \pi$ stacking, facilitating its intracellular uptake.
\end{abstract}

(C) 2014 Elsevier B.V. All rights reserved.

\section{Introduction}

The chemistry of organotins has attracted much attention in recent years, owing to potential biological and industrial applications. The organotin(IV) compounds have shown a wide variety of biological activities: bactericidal, fungicidal, biocidal and pesticidal [1]. In addition, many organotin(IV) compounds have been tested for their in vitro activity against a large variety of tumor cell lines and have been found to be as effective, or better, than traditional

\footnotetext{
* Corresponding author. Address: Dipartimento di Scienze e Tecnologie Biologiche, Chimiche e Farmaceutiche (STEBICEF), Università di Palermo, viale delle Scienze Ed. 16, Parco d'Orleans II, 90128 Palermo, Italy. Tel.: +39 091 23897967; fax: +390916577270

E-mail address: assunta.girasolo@unipa.it (M.A. Girasolo).
}

heavy metal anticancer drugs such as cisplatin [2]. In general, the biochemical activity of organotin(IV) complexes is influenced greatly by the structure of the molecule and the coordination number of the tin atoms [3]; it is well known that the biological activity of organotin(IV) complexes is related to the number of $\mathrm{Sn}-\mathrm{C}$ bonds and the type of groups in the organotin moiety. The organotin(IV) compounds with triazolopyrimidine ligands have not been investigated to a large extent. Considering that organotin(IV) compounds are promising also in cancer therapy, we have decided to study a class of $\mathrm{R}_{2} \mathrm{SnCl}_{2}(\mathrm{~L})_{2}$ and $\mathrm{R}_{2} \mathrm{SnCl}_{2}(\mathrm{~L})$ type complexes $(\mathrm{R}=\mathrm{Me}$, Et, ${ }^{n} \mathrm{Bu}, \mathrm{Ph}$ and $\mathrm{L}=\mathrm{dbtp}$ or dptp).

Triazolopyrimidines [4] represent an interesting class of heterocycles due to the number and the arrangement of the nitrogen atoms in the aromatic cycle as well as the nature of the ring substituents. Some transition metal complexes (e.g. $\mathrm{Ag}(\mathrm{I}), \mathrm{Cu}(\mathrm{II}), \mathrm{Pt}(\mathrm{II})$, and $\mathrm{Pd}(\mathrm{II}))$ with triazolopyrimidines significantly inhibit the in vitro cell 
growth of Gram(+) and Gram(-) bacteria. The antitumor activity studies (in vitro) of cis-dichloro platinum(II) compounds with triazolopyrimidine ligands dbtp and dptp [5] indicate a moderate antiproliferative activity against the cells of rectal, breast and bladder cancer. Cytotoxicity parameters pointed out that the antitumor activity of the investigated platinum(II) compounds containing 1,2,4-triazolo[1,5-a]pyrimidines depends directly on the geometry around platinum(II) and the kinds of ligands involved. When the antitumor activity of the triazolopirymidine complexes is related to substitutions in the pyrimidine ring, their electronic and stereochemical impact is unequivocal. Previous studies on cis-dichloro platinum(II) compounds with 5,7-disubstituted-1,2,4-triazolo $[1,5-a]$ pyrimidines suggested that the presence of a bulky ligand (tert-butyl or a phenyl group in the triazolopyrimidine ring) might be a major factor in the antitumor activity of the platinum(II) compounds [6]. Reported X-ray structures confirmed the presence of monodentate triazolopyrimidines in many coordination compounds; in each case the heterocyclic ligand binds via $\mathrm{N}(3)$, in mononuclear Pt(II) [7], Pd(II) [8] and Ru(III) [9] coordination compounds. A special feature of these complexes is that they were modeled on the active square-planar Pt(II) complexes which have cis halogen groups and yet the mode of action for the formation of metal-based cross-links is reported to follow a different route for organotin adducts [10]. Among the diorganotin(IV) compounds, di- $n$-butyltin(IV) derivatives have received more attention due to their antitumor activity stronger than that of dimethyltin(IV) or diethyltin(IV) analogs. However, their antitumor mechanisms of action are still not elucidated [11]. Investigations on 'induction of apoptosis' by metal-based drugs have become popular with cisplatin and ruthenium compounds, suggesting that apoptosis is a possible key event in mediating the in vitro antitumor activity of these compounds. Inspired by the apoptosis mechanism of these metal-based antitumor complexes, we decided to check if the in vitro antitumor activity of organotin(IV) complexes could be related to apoptosis by cellular biochemical studies.

Recently, we described complexes of diorganotin(IV) dichlorides with the heterocyclic ligands $[1,2,4]$ triazolo-[1,5-a]pyrimidine (tp), 5,7-dimethyl-[1,2,4]triazolo-[1,5-a]pyrimidine (dmtp) [12], 5,7-ditertbutyl-1,2,4-triazolo[1,5-a]pyrimidine (dbtp) and 5,7-diphenyl-1,2,4-triazolo[1,5-a]pyrimidine (dptp) [13] that exhibit antibacterial activity against a group of reference pathogen micro-organisms, thus showing antibacterial activities against a group of reference pathogen micro-organisms, which shows their inhibitory effect. In vitro antimicrobial tests showed that ${ }^{n} \mathrm{Bu}_{2} \mathrm{SnCl}_{2}$ (dmtp) [12] has interesting properties as anti Grampositive and antibiofilm agent.

The present study was aimed to widen the knowledge about bio-activity of organotin(IV) compounds. We here investigate inhibitory effects of complexes with triazolopyrimidine on the growth of a number of human malignant cell lines and assess the influence of the substituents (tert-butyl or phenyl) attached to the heterocyclic ring and the type of alkyl or phenyl groups attached to the tin atom, on their biological activity. The formerly characterized organotin(IV) compounds [13] assayed in this study were: $\mathrm{Me}_{2} \mathrm{SnCl}_{2}(\mathrm{dbtp})(\mathbf{1}), \mathrm{Me}_{2} \mathrm{SnCl}_{2}(\mathrm{dbtp})_{2}$ (2), $\mathrm{Et}_{2} \mathrm{SnCl}_{2}$ (dbtp) (3), $\mathrm{Et}_{2} \mathrm{SnCl}_{2}$ (dbtp) $)_{2}$ (4), $\mathrm{Et}_{2} \mathrm{SnCl}_{2}$ (dptp) (5), ${ }^{n} \mathrm{Bu}_{2} \mathrm{SnCl}_{2}$ (dbtp) $)_{2}$ (6), ${ }^{n} \mathrm{Bu}_{2} \mathrm{SnCl}_{2}$ (dptp) (7), $\mathrm{Ph}_{2} \mathrm{SnCl}_{2}$ (dbtp) (8), $\mathrm{Ph}_{2} \mathrm{SnCl}_{2}(\mathrm{EtOH})_{2}$ (dptp) $)_{2}$ (9). All complexes were evaluated for their in vitro anti-proliferative activity against three human cancer cell lines: HepG2 (human hepatocellular carcinoma), HeLa (human cervix adenocarcinoma) and MCF-7 (human breast cancer). The apoptosis of HepG2 cells induced by the most active complexes was also investigated using flow cytometry as well as fluorescence microscopy. Moreover, crystal structure of ${ }^{n} \mathrm{Bu}_{2} \mathrm{SnCl}_{2}$ (dptp), 7, whose spectroscopical parameters have been previously reported [13], is also discussed.

\section{Experimental}

\subsection{Diorganotin(IV) compounds, $R_{2} \mathrm{SnCl}_{2}(L)_{2}$ and $R_{2} \mathrm{SnCl}_{2}(L)$}

The synthesis and characterization of the compounds $\mathrm{R}_{2} \mathrm{SnCl}_{2}$ $(\mathrm{L})_{2}$ and $\mathrm{R}_{2} \mathrm{SnCl}_{2}(\mathrm{~L})(\mathbf{1 - 9})$ where $\mathrm{R}=\mathrm{Me}$, Et, ${ }^{n} \mathrm{Bu}$ and $\mathrm{Ph}$, while $\mathrm{L}=5,7$-di-tert-butyl-1,2,4-triazolo[1,5-a]pyrimidine (dbtp) and/or 5,7-diphenyl-1,2,4-triazolo[1,5-a]pyrimidine (dptp) (Scheme 1) were reported earlier [13] and will not be discussed here. Scheme 2 shows the proposed structures for $R_{2} S n L_{2}$ and $R_{2} S n L$ complexes.

\subsection{X-ray crystallography of ${ }^{n} \mathrm{Bu}_{2} \mathrm{SnCl}_{2}$ (dptp) (7)}

Crystals of 7, suitable for the X-ray diffraction studies, were grown on slow evaporation of a methanol solution of the complex (Fig. 1). Preliminary examination and data collection were carried out at ambient temperature on a Sapphire CCD detector (Oxford Diffraction Ltd., Agilent Technologies, USA) with Mo K $\alpha$ radiation, $\lambda=0.71073 \AA$, monochromator graphite.

Data reduction was automatically performed by CrysAlisPRO (Oxford Diffraction Ltd., UK). The cell parameters were obtained and refined using the PHICHI [14] and DIRAX [15] programs, respectively, catching reflections with random orientation in $h k l$ planes. Intensities were corrected by Lorentz polarization and absorption with the SADABS [16] program. The XPREP [17] program was used for analysis of the data reduction and revealed an orthorhombic P group. The structure was solved by direct methods using the SHELXs-97 [18] program. SHELX-97 was used for structure solution and refinement based on $F^{2}$. The asymmetric unit contains two crystallographically independent molecules, $\mathbf{A}$ and $\mathbf{B}$, two conformers differing in both the butyl groups and the phenyl ring orientations Fig. 2. The butyl moieties, particularly those of molecule $\mathbf{B}$, are characterized by large thermal vibrations; however, no satisfactory alternative model for the disordered atoms could be refined despite repeated attempts. The two independent molecules were separately refined by blocked-matrix least squares methods, giving to each correspondent atom the same crystallographic numbering with A or B labels. Non-hydrogen atoms were refined isotropically, apart from $\mathrm{Sn}$ and $\mathrm{Cl}$ atoms. Hydrogen atoms bound to carbon atoms were added in calculated positions. Aromatic carbon atoms were refined with $U_{\text {iso }}(\mathrm{H})=1.2 U_{\text {eq }} \mathrm{C} \mathrm{sp}^{2}$ and methyl carbon s with $U_{\text {iso }}(\mathrm{H})=1.5 U_{\text {eq }} \mathrm{C} \mathrm{sp}^{3}$. Final $\mathrm{R}$ indexes for 249 parameters refined $R_{1}=0.0582[(I)>2 \sigma(I)]$ and 0.1807 for all 9256 data, $w R_{2}=0.11146[(I)>2 \sigma(I)]$, GooF $S=0.910$ for all data. Flack $x$ parameter $=-0.04$ with e.s.d $=0.05$.

Crystal data and details of measurements are reported in Table 1. Molecular graphics were prepared using ORTEP-3 for Windows [19].

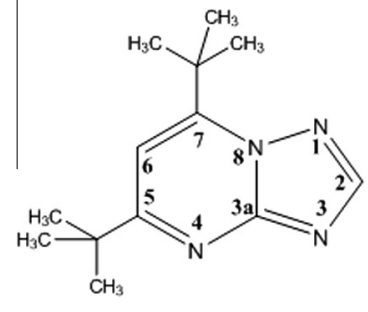

dbtp

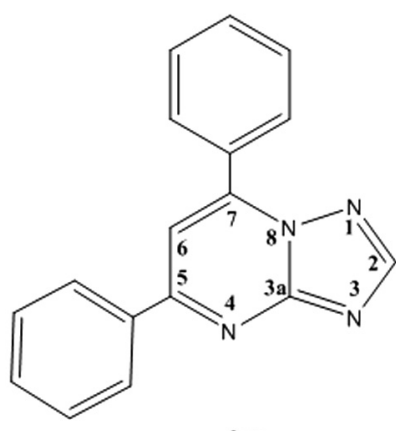

dptp
Scheme 1. The structure of ligands dbtp and dptp. 


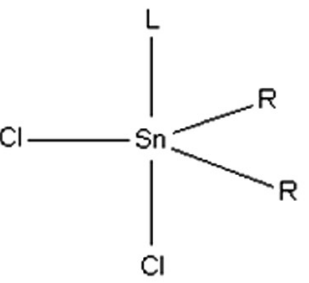

(a)<smiles>[R][Sb]([R])([3H])(Cl)(Cl)Cl</smiles>

(b)<smiles></smiles>

(c)

Scheme 2. Proposed structures [Ref. 13] for $\mathrm{R}_{2} \mathrm{SnL}$ and $\mathrm{R}_{2} \mathrm{SnL}_{2}$ complexes: (a) $\mathrm{R}=\mathrm{Me}$, Et, ${ }^{n} \mathrm{Bu}, \mathrm{Ph} ; \mathrm{L}=\mathrm{dbtp}$ and/or dptp (compounds 1,3,5,7,8). (b) $\mathrm{R}=\mathrm{Ph} ; \mathrm{L}=\mathrm{dptp}$ (compound 9). (c) $\mathrm{R}=\mathrm{Me}, \mathrm{Et},{ }^{n} \mathrm{Bu} ; \mathrm{L}=\mathrm{dbtp}$ (compounds $\mathbf{2 , 4 , 6}$ ).

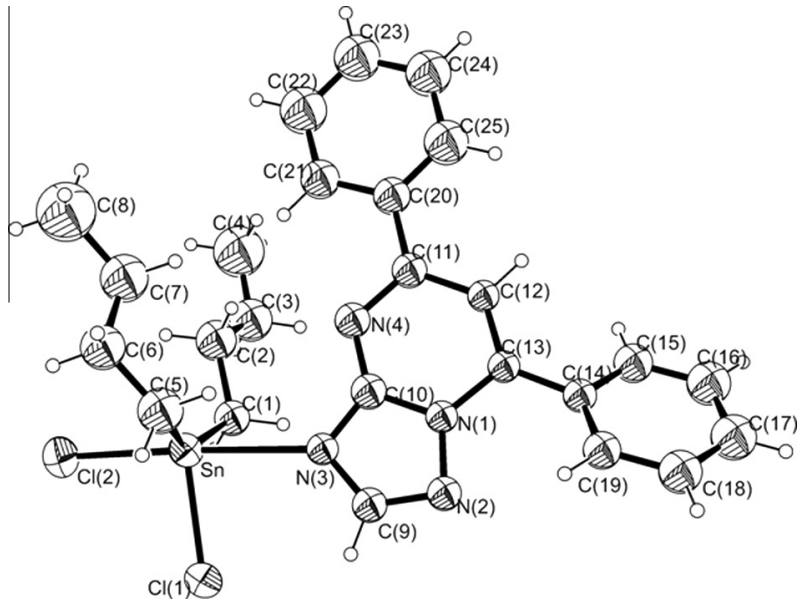

Fig. 1. Ortep drawing (30\% probability) of molecule $\mathbf{A}\left[{ }^{n} \mathrm{Bu}_{2} \mathrm{SnCl}_{2}\right.$ (dptp) (7)] showing the crystallographic numbering.

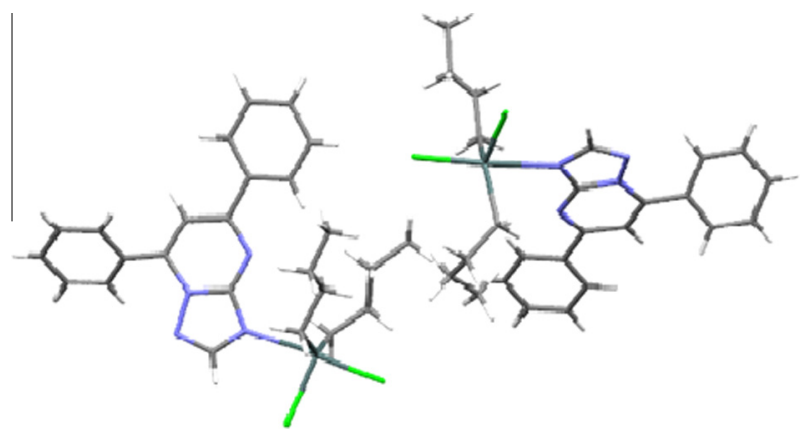

Fig. 2. Stick representation of molecules $\mathbf{A}$ and $\mathbf{B}\left[{ }^{n} \mathrm{Bu}_{2} \mathrm{SnCl}_{2}\right.$ (dptp) (7)] showing the different conformations of the butyl chains.

\subsection{Viability assay in vitro}

The tested complexes were dissolved in ethanol and then diluted in culture medium so that the effective alcohol concentration did not exceed $0.2 \%$. HepG2, HeLa and MCF-7 cell lines and human hepatic Chang liver cells were purchased from American Type Culture Collection, Rockville, MD, USA. All of them were grown in RPMI medium supplemented with L-glutamine ( $2 \mathrm{mM}), 10 \%$ fetal bovine serum (FBS), penicillin $(100 \mathrm{U} / \mathrm{mL})$, streptomycin $(100 \mu \mathrm{g} / \mathrm{mL})$ and gentamicin $(5 \mu \mathrm{g} / \mathrm{mL})$. HepG2 culture medium also contained sodium pyruvate $(1.0 \mathrm{mM})$. Cells were maintained in log phase by seeding twice a week at a density of $3 \times 10^{8}$ cells/L in humidified $5 \% \mathrm{CO}_{2}$ atmosphere, at $37^{\circ} \mathrm{C}$. In all experiments, cells were made quiescent through overnight incubation before the treatment with the compounds or vehicle alone (control cells). No differences were found between cells treated with ethanol $0.2 \%$ and untreated cells in terms of cell number and viability.

Cytotoxic activity of the organotin(IV) complexes against three human tumor cell lines HepG2, MCF-7, HeLa and human hepatic Chang liver cells was determined by the MTT colorimetric assay based on the reduction of 3-(4,5-dimethyl-2-thiazolyl)bromide2,5-diphenyl-2H-tetrazolium (MTT) [20] to purple formazan by mitochondrial dehydrogenases of living cells. This method is commonly used to illustrate inhibition of cellular proliferation. Monolayer cultures were treated for $24 \mathrm{~h}$ with various concentrations $(0.1-50 \mu \mathrm{M})$ of the drugs and cisplatin was used as the positive control. Briefly, all cell lines cells were seeded at $2 \times 10^{4}$ cells/ well in 96-well plates containing $200 \mu \mathrm{L}$ RPMI. After an overnight incubation, cells were washed with fresh medium and incubated with the compounds in RPMI. After a $24 \mathrm{~h}$ incubation, cells were washed, and $50 \mu \mathrm{L}$ FBS-free medium containing $5 \mathrm{mg} / \mathrm{mL}$ MTT were added. The medium was discarded after a $2 \mathrm{~h}$ incubation at $37^{\circ} \mathrm{C}$ by centrifugation, and formazan blue formed in the cells was dissolved in dimethyl sulfoxide (DMSO). The absorbance, measured at $570 \mathrm{~nm}$ in a microplate reader (Bio-RAD, Hercules, CA), of MTT-formazan of control cells was taken as $100 \%$ of viability.

$\mathrm{IC}_{50}$ value for each assessed compound was calculated by plotting the percentage viability versus concentration on a logarithmic graph and reading off the concentration at which $50 \%$ of cells remained viable relative to the control. Each experiment was repeated at least three times in triplicate to obtain the mean values.

\subsection{Measurement of phosphatidylserine exposure}

The externalization of phosphatidylserine (PS) to the cell surface was detected by flow cytometry by double staining with Annexin $\mathrm{V} /$ propidium iodide (PI). HepG2 cells were seeded in triplicate in 24 -wells culture plates at a density of $5.0 \times 10^{4}$ cells $/ \mathrm{cm}^{2}$. After an overnight incubation, the cells were washed with fresh medium and incubated with the compounds in RPMI. After $24 \mathrm{~h}$, cells were harvested by trypsinization and adjusted at $1.0 \times 10^{6}$ cells $/ \mathrm{mL}$ with combining buffer. One hundred microliters of cell suspended solution was added to a new tube, and incubated with Annexin V and PI solution according to the manufacturer's instructions (eBioscience, San Diego, CA) at room temperature in the dark for $15 \mathrm{~min}$. Then samples of at least $1.0 \times 10^{4}$ cells were subjected to fluorescence-activated cell sorting (FACS) analysis by Epics XL ${ }^{\mathrm{TM}}$ flow cytometer using Expo32 software (Beckman Coulter, Fullerton, CA), using appropriate 2-bidimensional gating method.

\subsection{Acridine orange and ethidium bromide morphological fluorescence dye staining}

Acridine orange (AO) stains DNA bright green, allowing visualization of the nuclear chromatin pattern and stains both live and dead cells. Ethidium bromide (EB) stains DNA orange but is 
Table 1

Crystal data and details of measurements for ${ }^{n} \mathrm{Bu}_{2} \mathrm{SnCl}_{2}$ (dptp).

\begin{tabular}{ll} 
Empirical formula & $\mathrm{C}_{25} \mathrm{H}_{30} \mathrm{Cl}_{2} \mathrm{~N}_{4} \mathrm{Sn}$ \\
Formula weight & 576.12 \\
$T(\mathrm{~K})$ & 298 \\
Wavelength $(\AA)$ & 0.71069 \\
Crystal system & orthorhombic \\
Space group & $P c a 2_{1}$ \\
$a(\AA)$ & $28.346(4)$ \\
$b(\AA)$ & $24.707(5)$ \\
$c(\AA)$ & $7.531(6)$ \\
$V\left(\AA^{3}\right)$ & 5274.30 \\
$Z$ & 8 \\
Density (Mg m & $-3)$ \\
Crystal size $(\mathrm{mm})$ & 1.451 \\
$\theta$ Range for data collection $\left(^{\circ}\right)$ & $0.20 \times 0.20 \times 0.35$ \\
Index range & $2.5-25$ \\
& $-33 \leqslant h \leqslant 33,-29 \leqslant k \leqslant 29$, \\
Reflections collected & $-8 \leqslant l \leqslant 8$ \\
Data/restraints/parameters & 9256 \\
Goodness-of-fit $(\mathrm{GOF})$ on $F^{2}$ & $9256 / 2 / 248$ \\
Final $R$ indices $[I>2 \sigma(I)]$ & 0.91 \\
& $R_{1}=0.0582, w R_{2}=0.1146$ \\
Largest difference in peak and hole & {$[\mathrm{R}=0.1807$ for all 9256 data] } \\
$\quad\left(\mathrm{e} \AA^{-3}\right)$ & $0.64-0.34$ \\
Flack parameter & $-0.04(5)$ \\
\hline
\end{tabular}

excluded by viable cells. Dual staining allows separate enumeration of populations of viable non-apoptotic, viable (early) apoptotic, nonviable (late) apoptotic, and necrotic cells. Live cells appear uniformly green. Early apoptotic cells stain green and contain bright green dots in the nuclei as a consequence of chromatin condensation and nuclear fragmentation. Late apoptotic cells incorporate EB and therefore stain orange, but, in contrast to necrotic cells, the late apoptotic cells show condensed and often fragmented nuclei. Necrotic cells stain orange, but have a nuclear morphology resembling that of viable cells, with no condensed chromatin. Briefly, after HepG2 cells were treated with the organotin(IV) compounds for $24 \mathrm{~h}$, the medium was discarded. Cells were washed with saline $5 \mathrm{mM}$ phosphate buffer (PBS) and then incubated with $100 \mu \mathrm{L}$ PBS containing $100 \mu \mathrm{g} / \mathrm{mL}$ of EB plus $100 \mu \mathrm{g} / \mathrm{mL}$ of AO. After $20 \mathrm{~s}, \mathrm{~EB} / \mathrm{AO}$ solution was discarded and cells immediately visualized by means of fluorescent microscope equipped with an automatic photomicrograph system (Leica, Wetzlar, Germany). Multiple photos were taken at randomly-selected areas of the well to ensure that the data obtained are representative.

\subsection{Cell cycle analysis}

Cell cycle stage was analyzed by flow cytometry. Aliquots of $1 \times 10^{5}$ cells were harvested by centrifugation, washed with (PBS) and incubated in the dark in a PBS solution containing $20 \mu \mathrm{g} / \mathrm{mLPI}$ and $200 \mu \mathrm{g} / \mathrm{mL}$ RNase, for $30 \mathrm{~min}$, at room temperature. The samples were then immediately subjected to FACS analysis. At least $1 \times 10^{4}$ cells were analyzed for each sample.

\section{Results and discussion}

\subsection{Crystal structure of ${ }^{n} \mathrm{Bu}_{2} \mathrm{SnCl}_{2}(\mathrm{dptp})$ (7)}

The crystal structure of $\mathbf{7}$ is shown in Fig. 1 as an Ortep representation (30\% probability) together with the atomic crystal numbering. Significant bond distances and angles are reported in Table 2. In agreement with IR and Mössbauer evidences [13], ${ }^{n} \mathrm{Bu}_{2} \mathrm{SnCl}_{2}$ (dptp) is a five-coordinated Sn species; X-ray diffraction studies confirm a distorted trigonal bipyramidal geometry with $\mathrm{N}, \mathrm{Cl}$ as axial atoms and $\mathrm{Cl}$ and butyl groups in the equatorial plane. The triazolopyrimidine unit coordinates to the $\mathrm{Sn}$ atom through
Table 2

Selected bond distances $(\AA)$ and angles $\left({ }^{\circ}\right)$ E.s.d.s are shown in parentheses.

\begin{tabular}{lrr}
\hline & Molecule A & Molecule B \\
\hline $\mathrm{Sn}-\mathrm{Cl}(1)$ & $2.371(4)$ & $2.339(4)$ \\
$\mathrm{Sn}-\mathrm{Cl}(2)$ & $2.439(4)$ & $2.436(4)$ \\
$\mathrm{Sn}-\mathrm{N}(3)$ & $2.576(8)$ & $2.556(9)$ \\
$\mathrm{Sn}-\mathrm{C}(1)$ & $2.074(9)$ & $2.117(9)$ \\
$\mathrm{Sn}-\mathrm{C}(5)$ & $2.081(8)$ & $2.031(9)$ \\
$\mathrm{Cl}(1)-\mathrm{Sn}-\mathrm{Cl}(2)$ & $94.7(1)$ & $94.2(1)$ \\
$\mathrm{C}(1)-\mathrm{Sn}-\mathrm{Cl}(1)$ & $104.7(4)$ & $107.0(5)$ \\
$\mathrm{C}(1)-\mathrm{Sn}-\mathrm{Cl}(2)$ & $96.8(4)$ & $101.0(5)$ \\
$\mathrm{C}(5)-\mathrm{Sn}-\mathrm{Cl}(1)$ & $109.4(5)$ & $113.6(5)$ \\
$\mathrm{C}(5)-\mathrm{Sn}-\mathrm{Cl}(2)$ & $97.5(4)$ & $97.4(5)$ \\
$\mathrm{N}(3)-\mathrm{Sn}-\mathrm{Cl}(1)$ & $82.6(2)$ & $81.6(3)$ \\
$\mathrm{N}(3)-\mathrm{Sn}-\mathrm{Cl}(2)$ & $177.4(3)$ & $80.9(5)$ \\
$\mathrm{N}(3)-\mathrm{Sn}-\mathrm{C}(1)$ & $83.5(4)$ & $83.8(5)$ \\
$\mathrm{N}(3)-\mathrm{Sn}-\mathrm{C}(5)$ & $83.8(5)$ & $133.6(4)$ \\
$\mathrm{C}(1)-\mathrm{Sn}-\mathrm{C}(5)$ & $141.5(6)$ &
\end{tabular}

Geometry of $\mathrm{C}-\mathrm{H} \cdots \mathrm{Cl}$ interaction.

$\mathrm{C}(16) \mathrm{A}-\mathrm{H}(16) \mathrm{A} \cdots \mathrm{Cl}(1) \mathrm{B} \mathrm{H} \cdots \mathrm{Cl}$ distance $2.91(1) \AA \AA \mathrm{C}-\mathrm{H} \cdots \mathrm{Cl}$ angle $170.8(6)^{\circ}$

$\mathrm{N}(3)$ in a monodentate mode, with $\mathrm{Sn}-\mathrm{N}(3)$ bond distance of 2.576(8) and 2.556(8) Å for molecule A and B respectively, trans to $\mathrm{Cl}(2), \mathrm{Sn}-\mathrm{Cl}(2) 2.439(4)$ and 2.436(4) $\AA$ for molecule $\mathbf{A}$ and $\mathbf{B}$ respectively (Fig. 2 ). The present distance [2.566 $\AA$ as an average] is well beyond the "threshold" for activity, according to Crowe [21]: actually, longer Sn-N bond lengths in diorganotin(IV) complexes containing an $\mathrm{N}$-donor atom, particularly greater than $2.39 \AA$, could apparently favour binding to DNA, whereas the inactive complexes had $\mathrm{Sn}-\mathrm{N}$ bonds $<2.39 \AA$ A. The rationale behind this is that the ligand predissociation may be an important step in the complex mode of action promoting the formation of a Sn-DNA complex, at least for bidentate $\mathrm{N}$ ligands. Our previous structural investigations on this class of complexes revealed that also compound 4 shows a quite long $\mathrm{Sn}-\mathrm{N}$ bond [2.603(2) $\AA$ ] while no comparison can be made for compound $\mathbf{9}$, where the $\mathrm{N}$ atom of the dptp moiety is H-bonded to the $\mathrm{O}$ atom of the ethanol $\mathrm{Sn}$ ligand, no direct Sn-N interaction being present [13].

The angles depicting coordination around the tin atom range from $177.4(3)^{\circ}$, for $\mathrm{N}(3)-\mathrm{Sn}-\mathrm{Cl}(2)$, the trans axial ligands, to the significantly distorted equatorial plane where there is a clear difference in the bond angles between the two conformers (molecule $\mathbf{A}$ and $\mathbf{B}$ in the crystallographic independent unit) due to the different butyl groups conformation and relative orientation. Actually, the angle $C(1)-S n-C(5)$ is $141.5(6)^{\circ}$ for the butyl groups of molecule $\mathbf{A}$ and $133.6(6)^{\circ}$ for molecule $\mathbf{B}$. That is, in molecule $\mathbf{A}$ both the butyl groups exhibit an anti conformation with a relative cisoid orientation of the ligands with respect to the $\mathrm{Cl}(1)-\mathrm{Sn}-\mathrm{Cl}(2)-\mathrm{N}(3)$ plane. $C(2)$ and $C(6)$ lie on the same side with respect to the above mentioned plane, thus widening the bond angle between $\mathrm{C}(1)$ and $\mathrm{C}(5)$. Overall, the $\mathrm{SnC}_{2} \mathrm{Cl}_{2} \mathrm{~N}$ center displays local $C_{2}$ site symmetry and the triazolopyrimidine plane comprises also the $C(20)$ to $C(25)$ phenyl ring, while $C(14)$ to $C(19)$ phenyl ring forms an angle of $28.7(3)^{\circ}$ with the previous one. In molecule $\mathbf{B}$, on the other hand, one butyl ligand exhibits an anti conformation while the other one has a gauche one, thus resulting in a local lack of symmetry, where neither phenyl ring lies exactly on the triazolopyrimidine plane.

Taking into account bond angles, perhaps a better description of the tin coordination for molecule $\mathbf{B}$ is that of a distorted square pyramid where $\mathrm{Cl}(2)$ occupies the axial site, while $\mathrm{Cl}(1), \mathrm{N}$ and the $C$ atoms define the base, according to a distorted cis- $\mathrm{R}_{2}$ trigonal bipyramidal structure determined by Mössbauer spectroscopy [13]. The other bond angles at the tin atom are the following: $\mathrm{C}(1)-\mathrm{Sn}-\mathrm{Cl}(1)$ angle $105.8(4)^{\circ}$ on average, $\mathrm{C}(5)-\mathrm{Sn}-\mathrm{Cl}(1)$ $109.4(5)^{\circ}$ and $113.6(5)^{\circ}$ for molecule $\mathbf{A}$ and $\mathbf{B}$ respectively. $\mathrm{N}(3)-$ $\mathrm{Sn}-\mathrm{C}(1)$ is $82.2(4)^{\circ}$ av., $\mathrm{N}(3)-\mathrm{Sn}-\mathrm{C}(5) 83.8(5)^{\circ}$ av., $\mathrm{Cl}(1)-\mathrm{Sn}-\mathrm{Cl}(2)$ $94.4(2)^{\circ}$ av., $\mathrm{Cl}(2)-\mathrm{Sn}-\mathrm{C}(1) 96.8(4)^{\circ}$ and $101.0(5)^{\circ}$ for $\mathbf{A}$ and $\mathbf{B}$ and 
Table 3

Calculated $\mathrm{IC}_{50}(\mu \mathrm{M})$ values ${ }^{\mathrm{a}}$ for anti-proliferative activity of organotin(IV) complexes against different human cell lines.

\begin{tabular}{|c|c|c|c|}
\hline \multirow[t]{2}{*}{ Compound } & \multicolumn{3}{|l|}{$\mathrm{IC}_{50} \pm \mathrm{SD}$} \\
\hline & HepG2 & MCF-7 & HeLa \\
\hline $\mathrm{Me}_{2} \mathrm{SnCl}_{2}(\mathrm{dbtp})(\mathbf{1})$ & $\mathrm{nd}^{\mathrm{b}}$ & $\mathrm{nd}^{\mathrm{b}}$ & $\mathrm{nd}^{\mathrm{b}}$ \\
\hline $\mathrm{Me}_{2} \mathrm{SnCl}_{2}(\mathrm{dbtp})_{2}(\mathbf{2})$ & $\mathrm{nd}^{\mathrm{b}}$ & $\mathrm{nd}^{\mathrm{b}}$ & $\mathrm{nd}^{\mathrm{b}}$ \\
\hline $\mathrm{Et}_{2} \mathrm{SnCl}_{2}(\mathrm{dbtp})(\mathbf{3})$ & $>50$ & $12 \pm 1.40$ & $>50$ \\
\hline $\mathrm{Et}_{2} \mathrm{SnCl}_{2}(\mathrm{dbtp})_{2}(\mathbf{4})$ & $>50$ & $15 \pm 1.10$ & $>50$ \\
\hline $\mathrm{Et}_{2} \mathrm{SnCl}_{2}(\mathrm{dptp})(\mathbf{5})$ & $20 \pm 1.50$ & $7.5 \pm 0.60$ & $20 \pm 1.50$ \\
\hline $\mathrm{Bu}_{2} \mathrm{SnCl}_{2}(\mathrm{dbtp})_{2}(\mathbf{6})$ & $1.0 \pm 0.11$ & $0.3 \pm 0.02$ & $1.2 \pm 0.09$ \\
\hline $\mathrm{Bu}_{2} \mathrm{SnCl}_{2}(\mathrm{dptp})(\mathbf{7})$ & $0.6 \pm 0.03$ & $0.7 \pm 0.05$ & $1.6 \pm 0.08$ \\
\hline $\mathrm{Ph}_{2} \mathrm{SnCl}_{2}(\mathrm{dbtp})(\mathbf{8})$ & $4.0 \pm 0.30$ & $4.8 \pm 0.05$ & $7.0 \pm 0.40$ \\
\hline $\mathrm{Ph}_{2} \mathrm{SnCl}_{2}(\mathrm{EtOH})_{2}(\mathrm{dptp})_{2}(\mathbf{9})$ & $3.0 \pm 0.25$ & $3.8 \pm 0.40$ & $7.5 \pm 0.50$ \\
\hline Cisplatin & $65 \pm 2$ & $10 \pm 1$ & $17.5 \pm 1.0$ \\
\hline
\end{tabular}

${ }^{\text {a }} \mathrm{IC}_{50}$ value for each assessed compound was calculated by plotting the percentage viability versus concentration on a logarithmic graph. Cisplatin was assayed as positive control. Results are the mean values \pm SD (standard deviation) of three separated experiment carried out in triplicate.

b nd-not detectable.

$\mathrm{Cl}(2)-\mathrm{Sn}-\mathrm{C}(5) 97.5(5)^{\circ}$ av. On the whole, the two conformers are stabilized by a single intermolecular $\mathrm{C}-\mathrm{H} \cdots \mathrm{Cl}$ interaction through the $\mathrm{C}(16)-\mathrm{H}(16)$ group belonging to an $\mathbf{A}$ molecule towards $\mathrm{Cl}(1)$ of a $\mathbf{B}$ molecule, thus yielding A-B hetero-dimers; the geometry of this interaction is reported in Table 2. Beside this H-bonding interaction, many $\pi-\pi$ and edge-to-face aromatic interactions contribute to the three-dimensional packing of the molecules. These latter interactions, interestingly, involve molecules belonging to the same conformers, i.e. among $\mathbf{A}$ molecules on one side and among $\mathbf{B}$ molecules on the other, where phenyl rings face towards the six-membered ring in triazolopyrimidine. Thus, a selective selfrecognition between "homo"-conformers drives the aromatic supramolecular assembly of the compound, while the H-bonding networks drives the "hetero" conformers recognition. This kind of shape-induced chiral ordering in 3-D packing, where chiral objects are produced from non chiral molecules, results in a very efficient enantiomeric close packing.

The presence of different conformers in the same crystal is occasional [22] and undoubtedly linked to the low energy difference among the different forms. However, it is known that even a slightly disfavored torsional geometry may be compensated by a better $\mathrm{H}$-bonding or aromatic interaction. Molecular conformation and hydrogen bonding (or $\pi \cdots \pi$ stacking interactions) can thus influence each other and, in turn, the overall crystal packing. In the present case, stabilization of the two conformers by the crystal packing may be relevant for activity. The activity of the cytotoxic complex 7 can be attributed to the ability of the ligand to form unobstructed $\mathrm{H}$-bonds and/or $\pi \cdots \pi$ stacking that may facilitate an intracellular uptake of complexes [23].

In addition, it must be pointed out the dual role of the Sn centre as a Lewis acid in order to coordinate the organic ligands and as a template in properly positioning the flexible moieties for new metal-based antitumour drugs, playing also its own part in inducing apoptosis. Chirality thus generated in crystal packing is certainly a very important aspect in determining stereoselective and stereospecific interaction with target molecules [24] while an increased bio-activity may be hypothesized due to the multifaceted binding mode of conformers. Actually, due to the recent serendipitous discovery of aspirin form II $[25,26]$ polymorphism in pharmaceutical chemistry has gained new impulse $[27,28]$.

\subsection{Cytotoxicity assay in vitro}

An investigation of cytotoxic activity in vitro of the organotin(IV) complexes 1-9 against three human tumor cell lines HepG2, MCF-7, HeLa and human hepatic Chang liver cells was

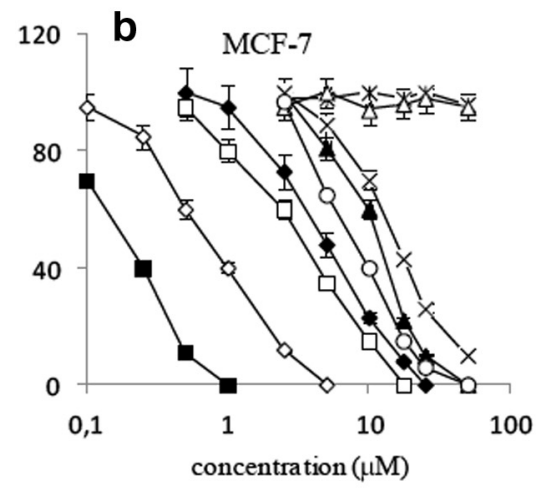

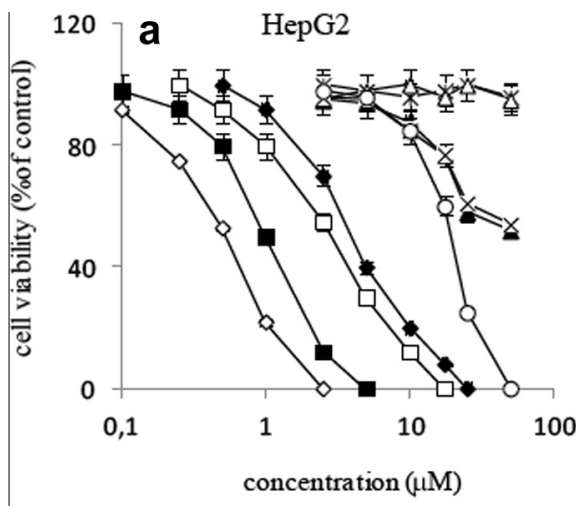

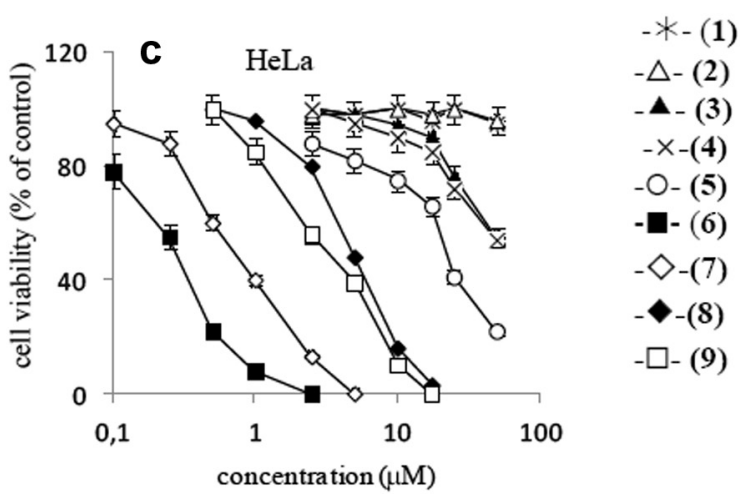

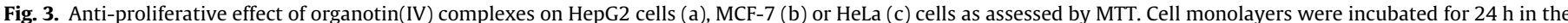

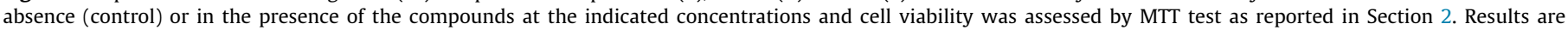
indicated as the percentage of viable cells with respect to untreated controls. Values are the mean \pm SD of three separate experiments carried out in triplicate. 


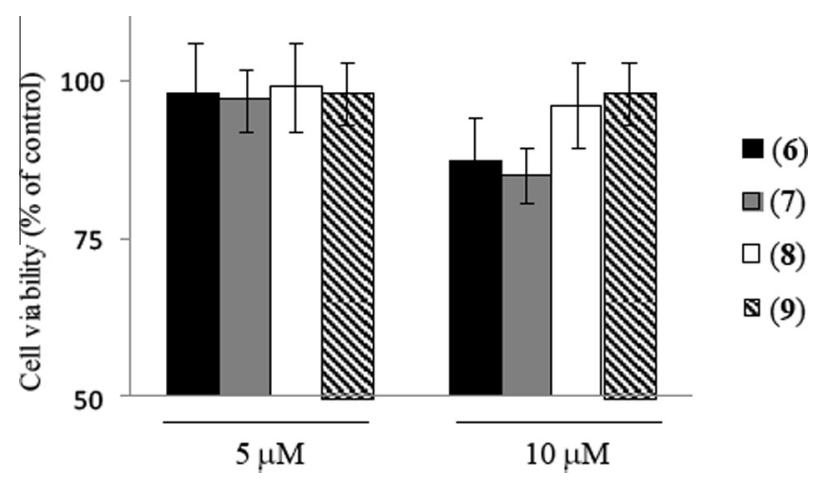

Fig. 4. Effect of the complexes 6-9 on viability of non tumorigenic Chang liver cells. Cell monolayers were incubated for $24 \mathrm{~h}$ in the absence (control) or in the presence of the compounds at the indicated concentrations and cell viability was assessed by MTT test as reported in Section 2. Results are indicated as the percentage of viable cells with respect to untreated controls. Values are the mean \pm SD of three separate experiments carried out in triplicate.

carried out in order to assess the possible relationship between the different tin moieties (bearing methyl, ethyl, butyl or phenyl groups), the coordination geometry and the cytotoxic activity. The $\mathrm{IC}_{50}$ values of the complexes against the selected tumor cell lines are listed in Table 3, and the cell viability is depicted in Fig. 3. Except for $\mathbf{1}$ and 2, which were ineffective, all compounds showed a significant dose-dependent antiproliferative effect against the three cell lines. These results are in good agreement with our earlier report [13] on antibacterial activity of the organotin(IV) complexes, the most active being $\mathrm{Ph}_{2} \mathrm{SnCl}_{2}$ and ${ }^{n} \mathrm{Bu}_{2} \mathrm{SnCl}_{2}$ derivatives. Comparing the $\mathrm{IC}_{50}$ values, the di-n-butyltin complexes $\mathbf{6}$ and $\mathbf{7}$ appeared most active against all the selected tumor cell lines, followed by diphenyltin complexes 8 and $\mathbf{9}$. Interestingly, complex $\mathbf{7}$ showed higher cytotoxic activity than $\mathbf{6}$ against HepG2 cells, but lower cytotoxicity than 6, towards MCF-7 and HeLa cells ( IC $_{50}$ values significantly different with $P<0.005$, Student's $t$ test). These results suggest that different complexes display different cytotoxic effects on different tumor cell lines. Among diethyltin(IV) complexes (3-5), complex 5 containing dptp as ligand, showed an overall anti-proliferative efficacy comparable to cisplatin, while 3 and 4, containing dbtp in 1:1 and 1:2 $\mathrm{M}$ ratio, respectively, were significantly less active. However, experiments performed to assay the activity of dbtp and dptp ligands used to synthesize the organotin(IV) complexes, demonstrated that these ligands were unable to exert any inhibitory activity (not shown). Among the nine organotin(IV) complexes checked, only compound 6-9 exhibit a strong activity against HepG2, MCF-7 and HeLa, being even more active than cisplatin, which is clinically widely used. Under the same assay conditions, compounds 6-9, did not substantially impaired the normal immortalized human Chang liver cells viability (Fig. 4). Only a modest effect (15\%) was observed after treatment with $\mathbf{6}$ and $\mathbf{7}$ at $10 \mu \mathrm{M}$, suggesting tumor cells as the main target of their cytocidal action.

On the basis of the data analysis, in agreement with what had been observed in previous studies [29], possible structure-activity relationships indicates that the biological activity of organotin(IV) series depended on both the ligand and the R groups bound to tin atom. Organo-R-groups appear to play an important role: indeed, the di- $n$-butyltin complexes $\mathbf{6}$ and 7, exhibit the strongest antitumor activity, while the diorganotin derivatives with a short (methyl, ethyl) carbon chain exhibit very low activities. The activity of diphenyltin(IV) $\mathbf{8}$ and $\mathbf{9}$, on the other hand, is lower compared
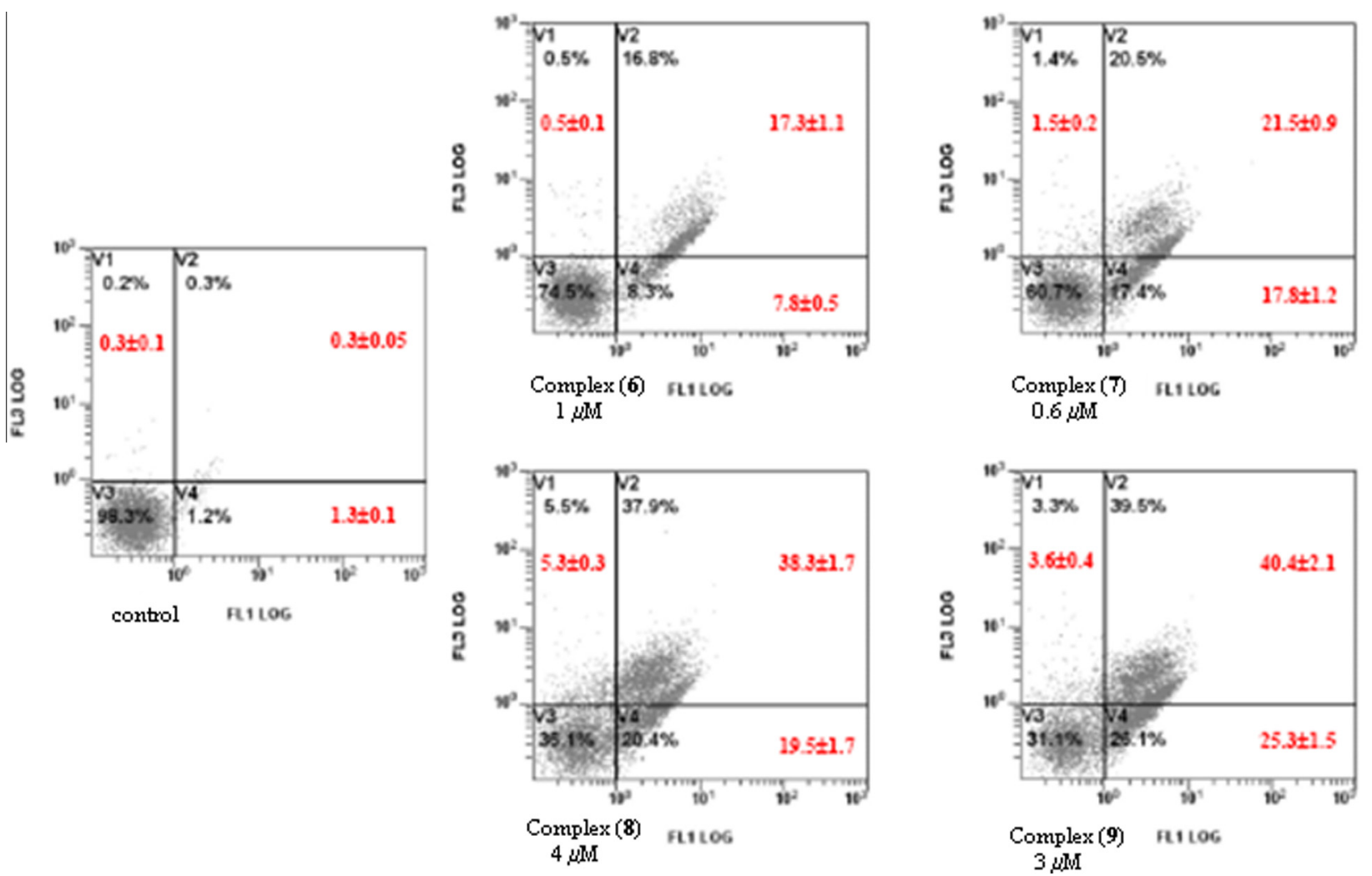

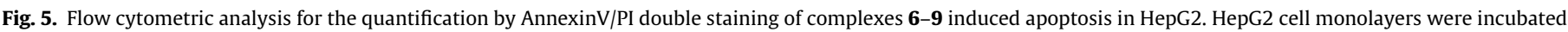

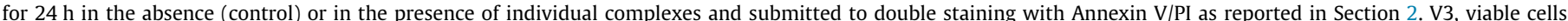

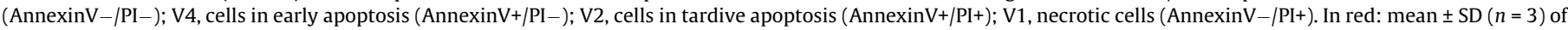
cells in the different apoptosis phases. Representative images of three experiments with comparable results. 
to of $\mathbf{6}$ and $\mathbf{7}$ complexes. Hence, for this class of organotin(IV) complexes, the activity follows the order ${ }^{n} \mathrm{Bu}>\mathrm{Ph}>\mathrm{Et}>\mathrm{Me}$ for the tested tumor cells. Moreover, taking into account the ligands, cytotoxity results in Table 3 indicate that $\mathbf{7}$ and $\mathbf{9}$, containing dptp ligands, exhibit better antitumor properties against HepG2 than $\mathbf{6}$ and 8 with dbpt ligands, as shown by their lower $(0.6-3.0 \mu \mathrm{M})$ $\mathrm{IC}_{50}$ values. On the other hand, 6 and 8 exhibit lower $\mathrm{IC}_{50}$ values against MCF-7 and HeLa.

The tendency to obtain inhibitory activity as a function of increasing lipophilicity in the series $\mathrm{Me}>\mathrm{Et}>{ }^{n} \mathrm{Bu}>\mathrm{Ph}$, which facilitates cell membrane crossing, well agrees with the known relationship between organotin toxicity and hydrophobicity [30,31].

In the present study, an attempt was made to compare the antitumor and antibacterial activity of the diorganotin(IV) complexes substituted with different alkyl (methyl-, ethyl- and $n$-butyl) and phenyl group. Our previous study [13] clearly indicated that 9 and $\mathbf{6}$ exhibit good antibacterial activity against Staphylococcus aureus ATCC29213, with a MIC value of 5 and $10 \mu \mathrm{g} \mathrm{mL}^{-1}$ respectively, and compound $\mathbf{6}$ showed an interesting activity against the methicillin resistant strain S. aureus ATCC43866 (MIC value of $20 \mu \mathrm{g} \mathrm{mL}^{-1}$ ). The compounds $\mathbf{7 - 9}$, on the other hand, resulted active against methicillin resistant Staphylococcus epidermidis RP62A.

\subsection{Apoptosis studies}

Cell death can usually occurs by necrosis, inducing severe inflammation, or by apoptosis. Apoptotic cells are transformed into small membrane-bound vesicles (apoptotic bodies) which are engulfed in vivo by macrophages, and no inflammatory response is triggered. Therefore, induction of apoptosis is considered important in the development of anticancer drugs and apoptotic markers in cells treated with organotin(IV) complexes were investigated to rationalize their inhibitory effects on cell viability. On the basis of their cytotoxic effect, the most active complexes 6-9 were chosen and their concentration selected on the basis that it represented $\mathrm{IC}_{50}$ value at $24 \mathrm{~h}$. Analysis was carried out on HepG2 cell line against which the complexes 6-9 showed higher cytotoxicity than cisplatinum. In the earlier events of the apoptotic process, scrambling of plasma membrane causes PS translocation from the inner to the outer membrane [32]. Thus, PS is exposed to the external environment and can bind to the annexin V-FITC conjugate, for which PS has a high affinity [33]. On the latest stages of the apoptotic process, as well as in necrotic processes, cell membranes lose their integrity, allowing PI to access the nucleus and intercalate between the DNA bases. FACS analysis using annexin V-FITC/PI double staining, allows to differentiate viable cells (annexin $\mathrm{V}-$ and $\mathrm{PI}-$ ) from early (annexin V+ and PI-) or late apoptotic (annexin $\mathrm{V}+$ and $\mathrm{PI}+$ ) and necrotic (annexin $\mathrm{V}$ - and $\mathrm{PI}+$ ) cells. As shown in Fig. 5 none of the complexes exerted necrotic effects on HepG2 cells, while inducing a clear pro-apoptotic effect with cells distributed between early and late apoptosis.

Morphological evidence of apoptosis was obtained by a staining method utilizing AO and EB which allows the identification of viable, apoptotic, and necrotic cells based on color and appearance. Under the fluorescence microscope, live cells appear green with intact nuclei whereas necrotic cells, showing a nuclear morphology resembling that of viable cells, stain red. Apoptosis is demonstrated by the appearance of cell shrinkage with condensation and breaking up of the nuclei. Apoptotic cells were easily distinguished from necrotic cells because the latter appeared orange with a normal nuclear structure. As shown in Fig. 6, non-treated living HepG2 cells (control) appeared uniformly green indicating integrated structure and normal size. After $24 \mathrm{~h}$ exposition to the complexes 6-9, cells in early apoptotis were observed, containing bright green patches in the nuclei as a consequence of chromatin condensation and nuclear fragmentation. Moreover, fluorescing orange cells, presenting cell shrinkage, chromatin condensation, nuclear fragmentation, and formation of apoptotic bodies were also evident as cells in late apoptosis (Fig. 6).

\subsection{Cell cycle distribution analysis by flow cytometry}

The effects of the complexes 6-9 on HepG2 cell cycle distribution was determined by flow cytometric analysis after staining of DNA with PI. Differentiation between phases of the cell cycle is based on the content of genetic material, which in non-dividing cells is limited to one copy of DNA. The cell population in the $\mathrm{S}$
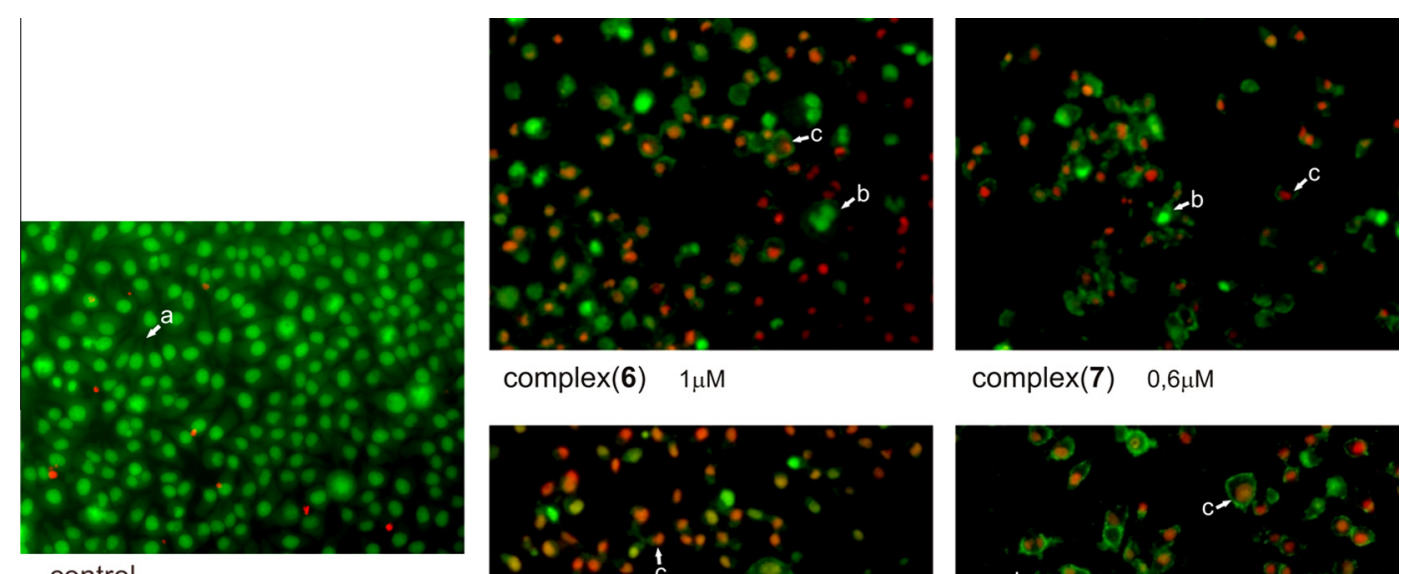

complex(6) $1 \mu \mathrm{M}$

complex(7) $\quad 0,6 \mu \mathrm{M}$
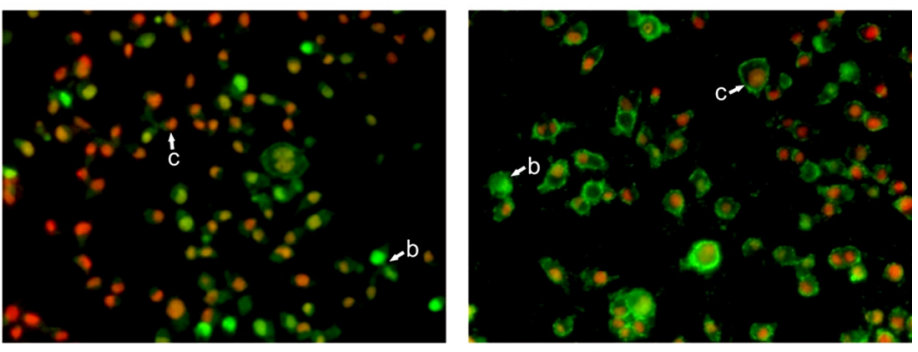

complex(8) $4 \mu \mathrm{M}$

complex(9) $3 \mu \mathrm{M}$

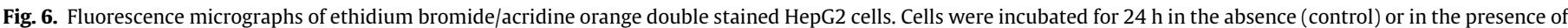

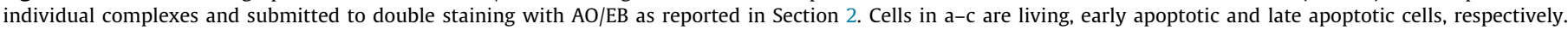
Representative images of three experiments with comparable results (200x magnification). 

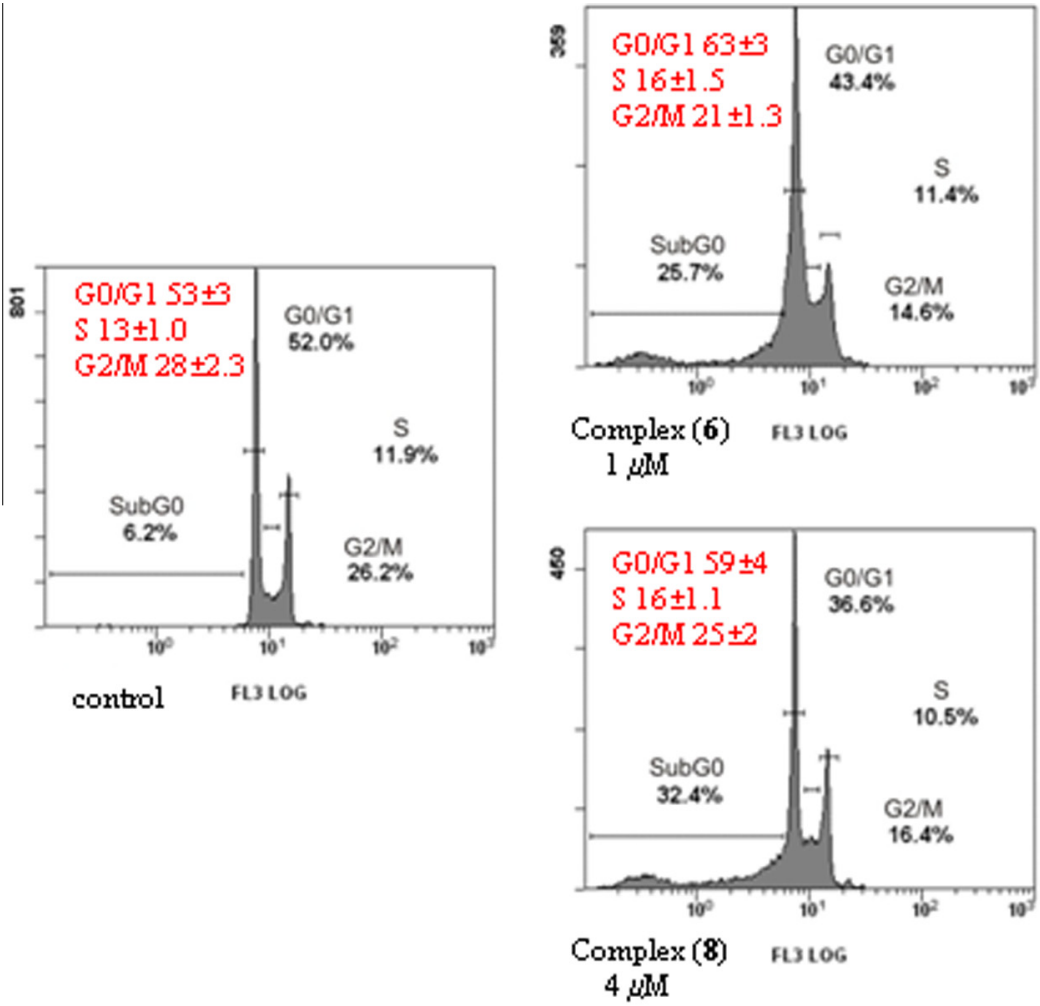
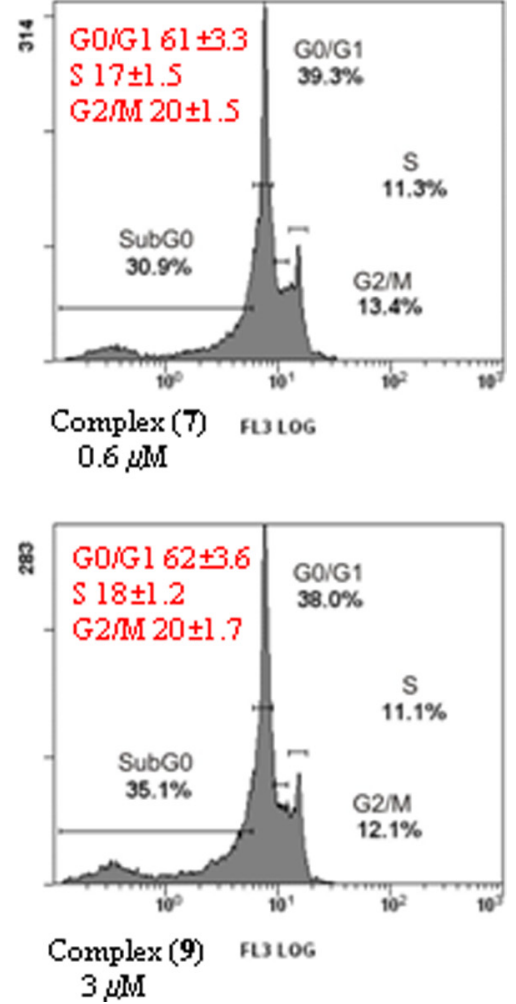

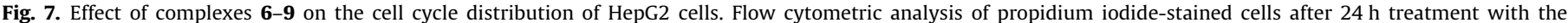

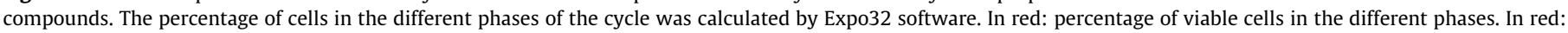

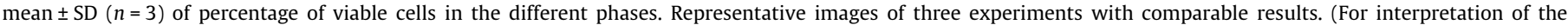
references to colour in this figure legend, the reader is referred to the web version of this article.)

phase (DNA replication phase) is synthesizing genetic material, and thus contains more DNA than quiescent cells. The subsequent $\mathrm{G} 2 / \mathrm{M}$ phase (interphase/mitosis) is characterized by the presence of two copies of DNA. At last, cells in the subdiploid region is considered as an index of apoptosis. Therefore, the alterations in these phases are used as a basis for comparing different treatments.

As shown in Fig. 7, the complexes 6-9 caused an accumulation of treated cells in subG0/G1 phase, confirming their cytotoxic effects, and induced a marked cell arrest in G0-G1 phase of the cycle (more than 60\%). These findings may suggest that these complexes can affect the cell mechanisms promoting DNA duplication.

\section{Conclusions}

The compounds 1-9 were screened in vitro against three human cancer cell lines, HepG2 (human hepatocellular carcinoma), HeLa (human cervix adenocarcinoma) and MCF-7 (human breast cancer) and with the normal immortalized human Chang liver cells as a selectivity control. The nature (alkyl/phenyl) and size of covalently attached $R$ groups of $S n(I V)$ atom played a key role in the toxicities of the reported complexes. Di- $n$-butyltin- and diphenyltin derivatives 6-9 showed cell growth-inhibitory potencies, expressed as $\mathrm{IC}_{50}$ values, much higher than cisplatin, the most clinically established chemotherapeutic drug. The cell death mechanism exerted by the organotin(IV) derivatives was apoptosis, as established in HepG2 cells by flow cytometric analysis of externalization of plasma membrane phosphatidylserine externalization and fluorescence microscopy after double staining with AO and EB. According to results from cytofluorimetric analysis of PI-stained cells, complexes 6-9 appeared to inhibit cell entry in S-phase, thus inducing cell death. Future studies will focus on the molecular mechanisms by which organotin(IV) complexes induce cell cycle arrest.
The molecular structure of the compounds 4 and $\mathbf{9}$ was previously investigated [13] and in the present study X-ray diffraction data of compound $\mathbf{7}$ are reported. The results obtained confirm the importance of both conformational flexibility in molecules provided with biological activity, because typical drug molecules represent a confluence of conformational mobility and functional complexity, and chirality in hitting the biological target. The lower $\mathrm{IC}_{50}$ values exhibited by compounds $\mathbf{7}$ and $\mathbf{6}$, compared to the other tested compounds, seem to suggest the singularity of the features possessed among the other complexes investigated, of which, apart from 4 and $\mathbf{9}$, unfortunately no solid state structure is available for comparison.

In conclusion, it has been recently established that the $\left[\mathrm{R}_{2} \mathrm{Sn}(\mathrm{IV})\right]^{2+}$ compounds with maximum antitumor activity combined with low mammalian toxicity are adducts of the type $\mathrm{R}_{2} \mathrm{SnX}_{2} \mathrm{~L}_{2}(\mathrm{X}=$ halogen, pseudohalogen, $\mathrm{L}=\mathrm{O}$ - or $\mathrm{N}$-donor ligand). A large number of compounds have now been screened against a variety of tumor cell lines, and several reviews have been published as shown above. Structural features of diorganotin(IV) complexes containing an N-donor atom, particularly longer Sn-N bond length, could apparently favour binding to DNA, whereas the inactive complexes had $\mathrm{Sn}-\mathrm{N}$ bonds shorter than $2.39 \AA$, at least for bidentate $\mathrm{N}$ ligands. The $\mathrm{Sn}-\mathrm{N}$ bond length in the highly active complex 7, well beyond the "threshold" for activity, can be compared to the results obtained from the investigations of the crystal structures of compounds $\mathbf{4}$ and $\mathbf{9}$. Actually, while $\mathbf{4}$ shows only a modest anti-proliferative activity in vitro, $\mathbf{9}$ behaves much better than cisplatin, showing also selectivity towards tumor cells. In our opinion, reasons for determining activity or inactivity of organotin(IV) compounds with monodentate $\mathrm{N}$-donor are much more the result of an interplay of favorable steric, enantiomeric and conformational factors summed up to the nature of the organotin(IV) ligands than the single geometric parameters. 
Hopefully, further structural studies will cast some light on elucidation of their mechanism of action.

\section{Acknowledgments}

Financial support by the Ministero dell'Istruzione, dell'Università e della Ricerca, Rome and by the Università degli Studi di Palermo is gratefully acknowledged.

\section{Appendix A. Supplementary material}

CCDC 997203 contains the supplementary crystallographic data for this paper. These data can be obtained free of charge from The Cambridge Crystallographic Data Centre via www.ccdc.cam.ac.uk/ data_request/cif. Supplementary data associated with this article can be found, in the online version, at http://dx.doi.org/10.1016/ j.ica.2014.07.015.

\section{References}

[1] A. Davies, M. Gielen, K.H. Pannell, E.R.T. Tiekink, Tin Chemistry: Fundamentals, Frontiers, and Applications, John Wiley \& Sons, Chichester, U.K., 2008.

[2] S.K. Hadjikakou, N. Hadjiliadis, Coord. Chem. Rev. 253 (2009) 235 (and references therein).

[3] L. Pellerito, L. Nagy, Coord. Chem. Rev. 224 (2002) 111.

[4] J.M. Salas, M.A. Romero, M.P. Sánchez, M. Quirós, Coord. Chem. Rev. 193-195 (1999) 1119.

[5] I. Łakomska, Inorg. Chim. Acta 362 (2009) 669.

[6] I. Łakomska, M. Fandzoch, B. Popławska, J. Sitkowski, Spectrochim. Acta, Part A 91 (2012) 126

[7] J.A.R. Navarro, J.M. Salas, M.A. Romero, R. Vilaplana, F. Gonzales-Vilchez, R. Faure, J. Med. Chem. 41 (1998) 332

[8] J. Ruiz, M.D. Villa, N. Cutillas, G. Lopez, C. de Haro, D. Bautista, V. Moreno, L. Valencia, Inorg. Chem. 47 (2008) 4490.
[9] A.H. Velders, A. Bergamo, E. Alessio, E. Zangrando, J.G. Haasnoot, C. Casarsa, M. Cocchietto, S. Zorzet, G. Sava, J. Med. Chem. 47 (2004) 1110.

[10] A.K. Saxena, F. Huber, Coord. Chem. Rev. 95 (1989) 109.

11] X. Shang, N. Ding, G. Xiang, Eur. J. Med. Chem. 48 (2012) 305.

12] M.A. Girasolo, C. Di Salvo, D. Schillaci, G. Barone, A. Silvestri, G. Ruisi, J. Organomet. Chem. 690 (2005) 4773.

[13] M.A. Girasolo, L. Canfora, P. Sabatino, D. Schillaci, E. Foresti, S. Rubino, G. Ruisi, G. Stocco, J. Inorg. Biochem. 106 (2012) 156

[14] A.J. Duisenberg, R.W.W. Hooft, A.M.M. Schreurs, J. Kroon, J. Appl. Crystallogr. $33(2000) 893$

[15] A.J.M. Duisenberg, J. Appl. Crystallogr. 25 (1992) 92.

[16] G.M. Sheldrick, SADABS, University of Göttingen, Germany, 2004.

[17] G.M. Sheldrick, XPREP, Bruker-Nonius AXS; Madison, WI, USA, 2005.

[18] L.J. Farrugia, WinGX, Version 1.80.05, An Integrated system of Windows programs for the solution, refinement and analysis of single crystal X-ray diffraction data. J. Appl. Crystallogr. 32 (1999) 837.

[19] L.J. Farrugia, ORTEP-3 for Windows version 2.02, J. Appl. Crystallogr. 30 (1997) 565.

[20] F. Denizot, R. Lang. J. Immunol. Meth. 89 (1986) 271.

[21] A.J. Crowe, P.J. Smith, G. Atassi, Inorg. Chim. Acta 93 (1984) 179.

[22] A. Nangia, Acc. Chem. Res. 41 (2008) 595.

[23] B. Ruan, Y. Tian, H. Zhou, J. Wu, R. Hu, C. Zhu, J. Yang, H. Zhu, Inorg. Chim. Acta 365 (2011) 302.

[24] S. Tabassum, A. Asim, R.A. Khan, Z. Hussain, S. Srivastav, S. Srikrishna, F. Arjmand, Dalton Trans. 42 (2013) 16749.

[25] P. Wishweshwar, J.A. McMahon, M. Oliveira, M.L. Peterson, M.Z. Zaworotko, J. Am. Chem. Soc. 127 (2005) 16802.

[26] A.D. Bond, R. Boese, G.J. Desiraju, Angew. Chem., Int. Ed. 46 (2007) 618.

[27] R. Hilfiker (Ed.), Polymorphism in the Pharmaceutical Industry, Wiley-VCH, Weinheim, Germany, 2006.

[28] H.G. Brittain, J. Pharm. Sci. 96 (2007) 705.

[29] (a) X. Shang, X. Meng, E.C.B.A. Alegria, Q. Li, M. Fátima, C. Guedes da Silva, M.L Kuznetsov, A.J.L. Pombeiro, Inorg. Chem. 50 (2011) 8158;

(b) H. Yin, C. Yue, M. Hong, J. Cui, Q. Wu, X. Zhang, Eur. J. Med. Chem. 58 (2012) 533;

(c) M. Nath, M. Vats, P. Roy, Inorg. Chim. Acta. 423 (2014) 70.

30] JJ. Cooney, S. Wuertz, J. Ind. Microbiol. Biotechnol. 4 (1989) 375.

[31] S. Ianelli, M. Orcesi, G. Pelizzi, F. Zani, J. Inorg. Biochem. 60 (1995) 89.

[32] D.L. Bratton, E. Dreyer, J.M. Kailey, V.A. Fadok, K.L. Clay, P.M. Henson, J. Immunol. 148 (1992) 514

[33] A.K. Hammill, J.W. Uhr, R.H. Scheuermann, Exp. Cell Res. 251 (1999) 16. 